\title{
The Red Snake
}

\author{
Francis Adams
}

Edited by Belinda McKay

\section{Editorial note}

There are two published versions of 'The Red Snake' by Francis Adams. The first appeared in The Christmas Boomerang, 24 December 1888: 17-18; the second in Francis Adams, Australian Life (London: Chapman and Hall, 1892, 3-24). The present edition is based on the Christmas Boomerang version. Revisions made by Adams for Australian Life have been incorporated where they correct errors or improve the literary qualities of the work, but not where their purpose is merely to remove Queensland references for an English audience. The accidentals (spelling and punctuation) of the first edition have been adopted here, rather than Queensland Review house style.

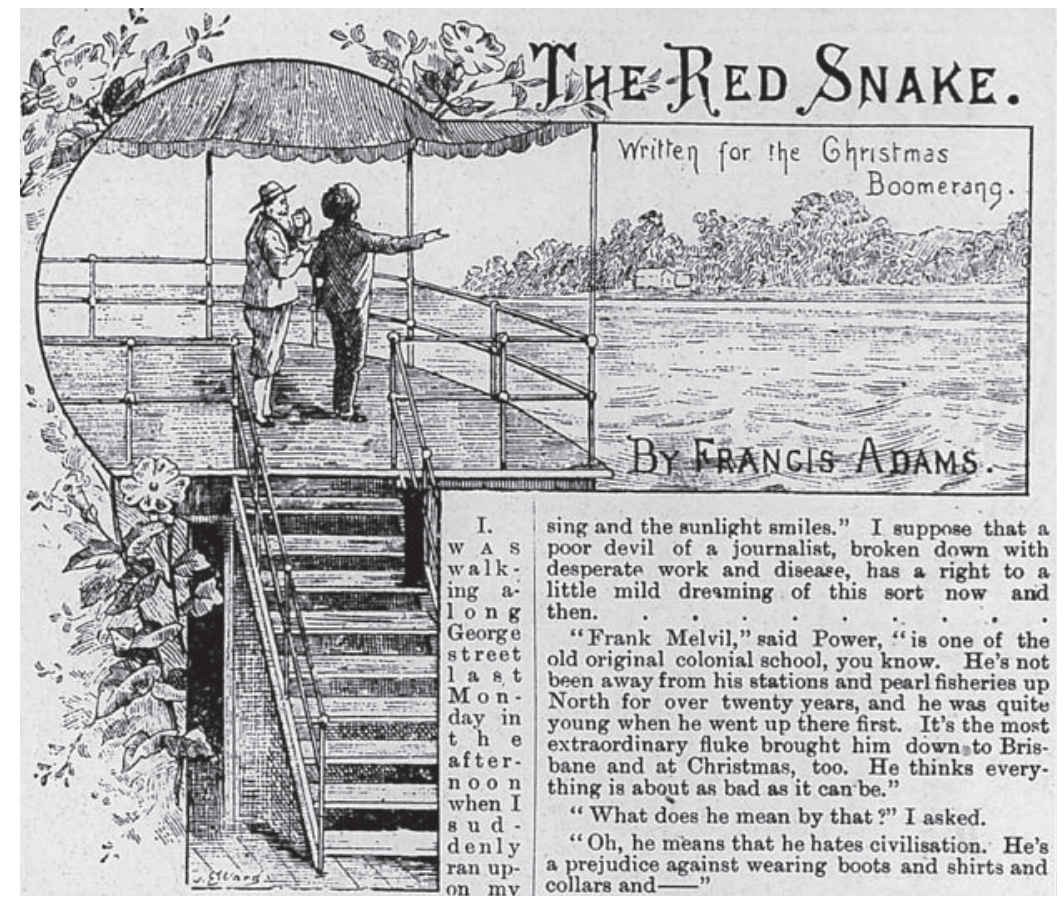

Figure 1: Title illustration by J.E. Ward for 'The Red Snake' by Francis Adams in The Christmas Boomerang, 24 December 1888: 17 


\title{
THE RED SNAKE.
}

\author{
Written for the Christmas Boomerang.
}

\author{
BY FRANCIS ADAMS.
}

I.

I was walking along George street last Monday in the afternoon when I suddenly ran upon my friend Power. ${ }^{1}$ Power is a man worth knowing. I suppose no one has been along the Australian coast, from Perth to Port Darwin, more often than he has. Is there a little port-town all round that he has not been in? Is there a river, navigable or unnavigable, that finds its way into Australian seas that he has not floated on? His stock of tales is the largest and best of anyone I know, and he has a sort of humorous kindliness about him, a genuine humanistic tolerance and appreciation, which has made him the friend of all sorts and conditions of men, women, and animals. ${ }^{2}$ He has the unctuous pleasure of discovering and understanding every oddity, and the light of this pleasure beams up in his eyes and on this lips and in his whole face as he sits opposite some abnormal piece of humanity in a cosy corner, just as when he pauses from his submarine work in his diver's dress to observe the antics of some eccentric denizen of the deep. ${ }^{3}$

"Look here," he said to me presently, after we had exchanged the usual preliminary small-talk and were pacing along towards the railway station, "look here, old man, I've got a fellow over at my diggings who's about one of the funniest fellows in the colony. You must come and see him.”

I intimated that I should be very pleased.

"P'raps you know him," said he, "or have heard of him, anyway - Frank Melvil - Melvil of Maidenhair Passage?"4

Both the names struck me as familiar, one of them (that of the place) as very familiar, but I could not say in what connection. He saw this by the look on my face and explained.

"You must have passed through Maidenhair Passage on your way up to Port Darwin. It's in the Coral Sea. It's the point where the Great Barrier Reef comes in closest to the coast. If you went through in the day-time you'd be sure to have noticed it. They always get up the passengers to see.” 
As he spoke, the vision of it rose up before me like a fairy vision. Let me try and recall it again. Early one winter's morning my friend Simmonds, the second officer, came into my cabin and cajoled me out to see what he called Maidenhair Passage. ${ }^{5}$ We were steaming along all day at full speed inside the Barrier Reef, anchoring at dusk and starting again at dawn. It was one long dream of balmy loveliness. I used to lie up on the poop in a wicker lounge-chair and doze and read Swinburne's first "Poems and Ballads" 6 and look at the sea and the sky and the coral islands and the land. Those smiling pale-blue tides and heavens, the gentle fall and swell of the inner barriered current and the somnolent sweet winy airs that blew from the brimming Pacific used to lull my overworked, sick, fevered personality into a state of mild and optimistic rapture which only deepened as the stars came out with their splendid and intense luminosity, Venus circling over the land, the dominant divinity of the galaxies, with a broad silver track on the dark waters. ${ }^{7}$ So far one thing alone had seemed wanting. Land and sea looked at one another like two parted lovers. We were too far off to realise the land except by snatches, glimpses of white-beached, scrub-covered coral islands or the everlasting sombre Australian coastal ridges. ${ }^{8}$ I came out on deck in my pyjamas, sipping at the cup of tea which the white-clothed Chinese "boy" had brought to me, and mounted on to the poop. Then in a moment I saw the perfection of the dual beauty, marine and terrestrial, their kiss and marriage clasp. We were in a regular passage, land on either side. The coast was to the left, a large coral island to the right; but far, far away over the golden-blue waters the sun rose up sheer from the limitless ocean. ${ }^{9}$ A thin, wavy ruffled line of white marked the breakers of the long, hidden, outer reef. All over the island the sunny tree-tops waved in the gentle breeze, the boughs shaking out their twigged leaves as if shivering with voluptuous delight. The clear, pure white sand of the cove beaches either shone like frosted silver or were cool and dark in the closer shadow. As the island was, so was the mainland, only of a beauty far richer. The beach, all lit up with the sunlight, ran right along, here and there broken by the dark-green mangroves, which grew right down into the crystal and mild water that was softly lipping all within its reach. ${ }^{10}$ The trees and dense tropical foliage, twined through with the graceful and serpentine creepers, pressed down to the shore. ${ }^{11}$ Up towards the narrowest part of the passage, built on piles, was a small wooden house. ${ }^{12}$ On the sand below and beside it two or three sail boats lay tilted on their sides. A little group of naked children splashed about or swam in the sunny shallows. Presently I could hear their shouts of laughter and merry calls, and snatches of the songs of the birds flitting from tree to tree came to me as I stood and watched and listened. Simmonds came up the ladder onto the poop and stood beside me. ${ }^{13}$

"That's Frank Melvil's place," he said, pointing to the house, "he's got a little pearl-shell fishery station here."

He told me something more about the man and the place, but I did not regard it. All I remember was standing there watching and listening and thinking of what life would be like in this "Eden of bland repose," "where the sea winds sing and the sunlight smiles." 14 I suppose that a poor devil of a journalist, broken down 
with desperate work and disease, has a right to a little mild dreaming of this sort now and then ...

"Frank Melvil," said Power, "is one of the old original colonial school, you know. He's not been away from his stations and pearl fisheries up North for over twenty years, and he was quite young when he went up there first. It's the most extraordinary fluke brought him down to Brisbane and at Christmas too. ${ }^{15} \mathrm{He}$ thinks everything is about as bad as it can be."

"What does he mean by that?" I asked.

"Oh, he means that he hates civilisation. He's a prejudice against wearing boots and shirts and collars and - "

"And trousers?"

“Well, I don't know he's got quite that far yet. When I was up at his pearlshell station he always wore trousers - except when he took it into his head to jump into the sea for a swim."

"And who lives with him up there? Is he married?"

“Frank Melvil? - married? Well, not quite! He doesn’t think enough of the common domestic civilised female to get married. Finds her too much trouble; not worth it. No; he lives alone up there with blacks and kanakas. He's South Sea Islanders for his pearl-shell boats, and a mob of blacks to look after the sheep or work about the house. ${ }^{16}$ He's a queer fellow. Sits or stands, looking or thinking, and taking no notice of you, for ten or fifteen minutes at a time. His brain works rather slow, too. You mustn't speak quick to him or he won't understand, but he'd never think of telling you so. It's too much trouble. He just goes on his own way and takes no notice. But, if he gets interested in anything, why — as the Yankees say — he's right there." ${ }^{17}$

"What originally took him up North?"

"Well, I'm hanged if I quite know. ${ }^{18}$ He comes of a very good family, I believe. He's an educated gentleman. There's no doubt about that. You can't hear him speak and not know it. Some people say he's a baronet if he cared to take the title. There was a Sir Alexander Melvil, a baronet, died six or seven years ago and left no children, and they say he was Frank Melvil's elder brother. ${ }^{19}$ I don't know. I hadn't the cheek to ask him when I was up at his place, and if I had asked him I don't expect he'd have taken any notice. Very likely he would have told me in his quiet dry way that the sooner I quitted the better. He's a queer fellow. You must come and see him."

"Do you know," I said, "I’ve a bit of a prejudice against these civilised people who go back into barbarism and loll away life there. ${ }^{20} \mathrm{I}$ own our civilisation is a frightful failure, of course, but oughtn't we, who see this, to stop and try and make it better, not slither away and live like animals? I've an idea I've heard that he was very cruel to the blacks. Wasn't he a police-magistrate, or something, and was dismissed for going on a massacring party?"21

"Well," said Power, "a man needn't be quite a fiend because he'll shoot blacks when his blood's up. I remember when all Cooktown turned out, after the blacks had been spearing fellows out on the runs, and drove a great swarm of them in upon Cape Bedford as you drive game. ${ }^{22}$ Cape Bedford's at the end of a little 
peninsula and ends in a barren rocky bluff. I wouldn't like to say how many blacks kicked out on that bluff when the ring closed in on them. Frank Melvil's a very decent fellow, take him all around, and kind-hearted too, and wouldn't hurt a fly unnecessarily. ${ }^{23}$ You can take my word for it, old man, for I know."24

At this point I perceived that a man in a cab was waving signals to Power, who responded, and the cab drew up to the pavement.

"Well," he said, "that's a chap I've been after this week. ${ }^{25}$ We've business. Good-bye, old man. If you want to see Frank Melvil and have a chat with him, turn up at my diggings to-morrow at six and have chow, if you're not spending your Christmas Day somewhere - or drop in afterwards in the course of the evening if you'd like it better. ${ }^{26}$ My best chin-chin to you!"27

We shook hands and I went on my way. I seemed to see the small wooden house, built on piles, up at the narrowest part of that fairy passage. The sail boats lay tilted on their sides on the sand below. The little group of naked children splashed about or swam in the sunny shallows. ${ }^{28}$ I could hear their shouts of laughter and their merry calls, and the snatches of the songs of the birds flitting from tree to tree came to me once more. Escaping by a sudden jump from the wheel of a buggy, whose owner was bawling at me as I loafed negligently over the crossing, it occurred to me that I must stop dreaming and attend to the daily proceedings of George-street and of my own business. ${ }^{29}$ After all it is probable, I thought, that I shall go to-morrow evening and see this owner of that "Eden of bland repose," "where the sea winds sing and the sunlight smiles." I was spending my Christmas Day nowhere but with my wretched self. ${ }^{30}$

\section{II.}

Power lives with a friend of his overlooking the river above North Quay. There they combine comfort and good cooking with a lovely prospect. The house is fairly large, divided into two by a passage down the middle. The whole of the left side is taken up by a big double room - study, sitting and dining-room in one - the far end opening out by two door-windows onto a broad veranda. Here in a variety of wicker lounges and easy chairs these luxurious bachelors are wont to smoke the best Manila via Hongkong cigars (imported free of duty) and look down, as from an eyrie, on to the road beneath and the blue winding river and clustering South Brisbane beyond. ${ }^{31}$ It was a lovely, mild, moonlight night with a faint cool breeze coming from the sea. ${ }^{32}$ Lighting a cigarette I came out from my boardinghouse, turned up George-street and made for my friend's house. ${ }^{33}$ I cannot say I was thinking much of Melvil or of anyone in Brisbane, unless it be of a dead girl who had passed from a small happy home that she had left desolate to lie in the grassy earth under the shadow of the city's western hills. ${ }^{34}$ Once or twice, as I passed on further by the illuminated houses behind their little gardens, fresh 
and exhaling with the recent rain, and heard the sounds of singing and laughter and music, the thought of another house, dark and empty, with blind windows reflecting the ghastly moonlight, came upon me and made me sad. Thus I reached my friend's garden gate, and, flinging away my burnt-out cigarette, opened it and went up the flight of wooden steps and over the veranda to the door and rang and knocked. ${ }^{35}$ Mary, the ill-favoured domestic, who can make curries fit for an eastern, opened it, and, when I had put down hat and stick in the hall, showed me into the room on the left. ${ }^{36}$ Dinner was not yet cleared away. Wine (and whisky) and dessert, with all that solid comely English luxury of cut-glass and fair linen and softly gleaming silver which Power affects, made the pleasant semi-artistic room more pleasant still. ${ }^{37}$ The shaded lamp cast a mellow light on everything, and outside on the far veranda the wide-flung garden windows showed two men at ease in their wicker chairs, backed by dark foliage, the silver-gleaming river, the still and moon-lit town. I came across the room and stood by the right doorwindow. ${ }^{38}$ The soft Brussels carpet, into which the feet pressed gratefully, had muffled the sound of my entry. The man in the easy chair just before me looked up slowly. It was not Power. It was not his "mate," Carlyle. It was no one, I knew at the first glance, but Melvil. I think I see the face now. Certainly it was fine one, full of suppressed and quiet force. The hair and beard were dark brown, streaked with grey, unkempt and straggling, yet waving naturally round the great moulded brow with its broad frowning bar, like a thunder-cloud over the brooding threat of the curiously regular and sculpturesque eyes. ${ }^{39}$ The gaze reminded me of the fixed inscrutable resolve of a sphinx. ${ }^{40}$ The nose was straight; the mouth red-lipped, impassive, and possibly rather brutal. ${ }^{41}$ All the rest of the face, except the prominent but delicately-lined cheek-bones and cheek, was hid by the hair, moustache, and beard. Power, who was lying in a lounge by the left door-window, jumped up at once and welcomed and introduced me to Melvil, who rose and shook hands with me. ${ }^{42}$ His hand-shake was cordial, his manner quite simple and easy. In a few minutes I was lying in the lounge, into which Power insisted on putting me - wine and whisky refused — one of his Isola d'Oro cigars accepted, and conversation progressing pleasantly. Power sat in another easy chair in the middle, in the depth of the shadow of the wall between the two windows. Melvil alone, his shoulders and head, that is, was in the light. He was smoking a clay pipe. The moon was in the south, illuminating all the front veranda, but leaving us here quite in the dark. I lay still, a little thoughtful and pre-occupied, yet watching the man's face with interest. ${ }^{43}$ He was speaking to me. His voice was low, but I have never heard one more musical. The slow cadences fell like a sound of deep running water. He said he knew some of my work. A chance visitor to Maidenhair Passage had brought with him a copy of a little novel of mine.

"I do not read a book in a year," he said, "I think reading is a mistake. It has been the cause of almost all the trouble and mischief in the world. But I took up your book by chance and did not put it down until I had finished it. It is all false and diseased, the wretched, civilised life you draw there, but you draw it truly." 44 
"If I had told you," said Power to me, laughing, "that Melvil had read 'Madeline Brown" 45 and would like to see the author, I knew you would not come. Similarly, if I had told Melvil that you had seen Maidenhair Passage had had heard a lot about its owner, I knew he wouldn't have let you come. It requires a little finesse to get two such shy birds onto the same perch."

"I begin to think," said Melvil quietly, "that you are a scoundrel, Power." He lifted his face and went on to me: ${ }^{46}$ "I cannot understand why you care to live in such a sphere as that which you have drawn in your book. I suppose it is the best which is to be found in these miserable, filthy civilised cities. ${ }^{47} \mathrm{I}$ was reading an article of yours in a Melbourne paper which Power gave me this afternoon, and you talked about the weary search for a new civilisation and a new life which goads the feverish modern man from city to city, from land to land. You had yourself passed from Melbourne to Sydney and then to Brisbane here, where you seemed to think you might find what you were seeking. That was foolish, as you have learned by now, I suppose?" 48

I acquiesced. It was a genuine pleasure to lie there and listen to this man talking. The speech was very singular in such a place; the sound of it was more singular still. But he paused now and I had to reply.

"That is true," I said, "but we end by accepting, not what we desire, but what we can get. And, after all, if we are dissatisfied with our civilisation, such as it is, ought we not to struggle to make it better, not leave it alone, to become what it pleases?”

"I do not think so. Other people's happiness does not concern me. If they are so foolish as to lead sickening existences and all the while pretend they are happy and keep boasting of it, that is their own look out."

"But the up-country life," said Power, "the life you have to lead out of reach of civilisation, it's all very well for a time, but a man gets tired of roughing it, as he does of everything else." 49

There was a pause.

"No," said Melvil, "no, I do not think so. If a man likes cant and pretence, he does. What is civilisation but pretence? Every social relation is a fraud. The very basis of it all - clothing - is one gigantic lie. For me, I prefer reality. A man's soul should be in his body, not in his clothes. This sickly, barbarous, 'civilised' hypocrisy disgusts me. Give us healthy, primal relations. They say we have sprung from apes, and certainly I think that we are going back to them." 50 "I," he proceeded in the same quiet tones, "do not think often of this. I think very little. But when I come down here into this wretched, dirty, stupid town I notice it.”

There was another pause, a long one.

Some one, evidently a girl, began playing on a piano a little way off. It was a simple air, a plaintive melody whose divinity has not been utterly discrowned by even vulgar and senseless abuse. ${ }^{51}$ This was the prelude to her singing, for presently I heard her voice..$^{52}$ It was a sweet voice, untutored, but somewhat marred by the occasional effort to sing with the detestable throaty twang which foolish pseudo-"musical" people think "fine." ${ }^{\text {" } 33}$ I conjured up the scene. The girl sitting, fingering rather unskilfully at the keys in her cool, white, summer dress, her face 
upraised a little, the light of the piano candles on it. ${ }^{54}$ The curtain bowing at the open window to the whispering pressure of the night breeze. No one else. Only I, looking and listening and thinking and remembering.

It would seem as if some similar train of thought had been suggested by the sounds of the mingled voice and piano to Power, if not to Melvil.

"I think we understand," said Power, "what you mean. I'm rather fond of savages, myself. I pick up their lingo quickly. And their ways amuse me. They are certainly simpler, or, when they lie, they lie as children do, and they don't in the least mind being found out. I don't really know but what I think their women are finer than ours. They don't last so long, of course, but they are as tender and faithful as dogs. Not the Chinese women; they are quite mercenary. But the Japs, or the Hindoos, and mostly any of the coloured races. They have eyes, some of them, like Gordon setters - great, deep, dark and liquid, full of love. There was a Jap girl I saw one day at Port Darwin, and she had eyes ... I say, Melvil," he broke off, "I've wondered often and often where I saw a girl before with eyes like hers, and now I remember. There was that girl at the Passage. I forget her name. It was the first morning after I came and we were walking along the beach. You recollect? She was carrying her baby down to the water. The little beggar couldn't walk yet, but he could swim like fun. She put him in the shallows and laughed at him, and then she jumped in herself and began playing with him, taking him out into the deep water. ${ }^{55}$ We stood and watched them. That was the girl. Her eyes were like that Port Darwin Jap girl's."

"Nini," said Melvil.

"Yes, Nini; that's her name. She had beautiful eyes. I remember her well. How is she?"

"She is dead."

"Dead?"

"She was killed just before I came down. The blackfellows caught her or decoyed her out into one of the back runs and speared her. ${ }^{56}$ They speared the child, too. It was mine.”

\section{III.}

He said this with his calm unvarying simplicity, and, after a moment's silence, proceeded:

"Nini and the child were the final expiation for the mysteries." 57

Our silence, full of a deep interest and suppressed curiosity, seemed to act on him. He raised his head a little and said:

"I was not living down on the shore then. It was five or six years ago. I had a log hut on the side of the first ridge. I had several here and there about the runs. ${ }^{58}$ The coast seems to be slowly rising all along that part. Very likely it is doing so 
all along the eastern slope. The first three ridges are of sand, with coral below, I expect. I had not really any idea that the blacks would trouble me. From time to time, of course, I had had to shoot or poison some, but not of late years. They were afraid of me. They thought I was a sorcerer or a god. This arose mostly from my invariable discovery of any of them who had stolen or speared my animals. The moment I found anything was missing, I used to get on my white horse, Leper (I have had three generations of Lepers); put two revolvers in my belt; take my rifle and ride off to the camp. ${ }^{59} \mathrm{I}$ always knew where they were. I had two or three blacks I could rely on. Five miles back there was a boora. That is a sacred spot, one of the places where the lads are initiated and become men. It is a curious formation, a small clump of hills with great exposed slabs of dark, granite-like rock towering up into the blue, with violent gorges and intricate caves. Everywhere about are the sacred carvings - rude pictures of animals and men, or of things, such as boomerangs and shields, or the lightning and the rain. These always interested me, and I was not satisfied till I understood them. But even my blacks, who were ready to do whatever I ordered them - to kill themselves if needs be - would not tell me about the carvings. ${ }^{60}$ They pretended they did not know, and I had to make them drunk to get at the truth, bit by bit, by threats and cajolery. I have spent whole days and nights alone in the boora among the hills, and I do not think there is much I do not now understand. Years ago, in North America, I unravelled the Red Indian carvings in the same way." 61

He paused for a moment, and, stirred though I was - curiously stirred, as at the approach of some mysterious influence - I yet remember hearing the notes of the piano, slow, soft, and clear, dreamily essaying the first bars of a melody full of smiles and tears.

"When I rode into the camp," he said, "I used to go straight up to the chief and tell him my grievance. Then I would have all the men and lads and gins put in a line and ride down it, looking at each. If the thief was a weak fool, he would be terrified as I fixed my eyes on him. If he were brave and had any intellect, he would be careless, but always too much, and generally a bit defiant. I always shot the thief on the spot - right through the heart. It is opposite one's barrel. Sometimes the thief would not be there, but be hidden away somewhere. Then I would demand him to be brought out, and ask if they thought they could fool me? Biame is the great god, the terrible power. ${ }^{62}$ He has many shapes, but it is always as something which strikes. On the stones he is the boomerang in full flight, or the spear, or above all the lightning. The initiation is by grades. First of all the god is shown under the figure of a man. Then he is recognised in the whirl of the boomerang; then in the rush and stab of the spear. Last of all he is to be known as the great exterior power - the irresistible flash of the lightning. I would say to the young men: 'I am Biame, the figure of the man!' Then to the others I would add, raising my voice and speaking to each according to his grade: 'Know me in the whirl of the boomerang! Know me in the rush and stab of the spear! Know me in the irresistible flash of the lightning! I am Biame. I slay 
you!' With that I would shoot the man right through the heart. It was because I knew their language and religion and social laws so well that I could bring new ideas of force and terror into them. At last the old men spoke to me openly of the mysteries, but with much cunning and inner reservations, trying to find me at fault. ${ }^{63}$ There are primal notions of theirs, vague, great, nature myths, which I have not yet grasped the meaning of and of which I do not think they themselves have any real idea. This last attempt to kill me came from the despair and jealousy of the most remarkable man I ever knew among them."

The girl had changed her mind and had ceased essaying that melody full of smiles and tears. Dreaming tenderly to herself she let her hands wander almost aimlessly over the keys, passing from piece to piece without scarcely being aware of it.

"I was riding close to the boora," he said, "one sunset. I never pass within four or five miles of it without going to it. I rode up by one of the gorges. ${ }^{64}$ Presently I was entirely in the deep, cold shadow. It struck me as deep and cold. I remember I thought for a moment of the old phrase in the Bible - the valley of the shadow of death. I was on my white horse - Leper, the son. At the top of the gully the rock suddenly rears up sheer, precipitous and flat. ${ }^{65} \mathrm{I}$ happened to look up. A man was clinging to the face of it hundreds of feet above me, lean, naked, with tightened muscles and intense gestures. ${ }^{66} \mathrm{I}$ knew in a moment what he was doing. He had been out there alone, fasting for days and nights, till the divine enthusiasm had come upon him, and now he was cutting out a sacred figure. I got down off Leper and stood and watched him for long. The light failed and still he worked on. It was the time of the full moon, which would rise up in the east over the sea and the coast. ${ }^{67}$ The dingoes were very restless, howling from time to time as they slouched through the scrub. ${ }^{68}$ They were always plentiful round the boora. The birds seemed restless, too. Still he worked on. The whole of his carving was already outlined and now he clambered up onto the summit of the rock to sharpen his flint axe. As he sat there squatting on his hams, his head bent down, rubbing round the flint in a hole in the rock, the moon rose slowly, huge, yellow, majestic in the pink pallor of the cloudless heaven. I knew it by the way he raised his head as the light reached him, and then, after a long pause, he began a low howling chant. I could not see what figure he had been cutting, but I guessed from his movements that it was a snake. ${ }^{69}$ Then I vaguely recalled the man. He had intellect. I think he must have seen me as I rode away out into the open, even if he had not heard the sounds of Leper's hoofs, though (I do not quite know why) I had been careful to keep off rock and stone as much as possible.”

He paused again. The dual lines of thought, suggested by his wonderful manner of telling all this and by the notes of the piano, proceeded unbrokenly as the girl came back to the original melody and played it with a sweet, lingering passion ${ }^{70}$ that made me seem ready to sob and weep.

"The next day at about the same time - that is about sunset - I was sitting at the door of the hut on the sand-ridge by myself when I suddenly saw a figure 
to the right of me in front of some bushes at the edge of the clearing. Two of the dogs were with me and they had not seen her yet. ${ }^{71}$ This struck me. She was looking at me fixedly - a young lubra, naked save for the little plaited rush-fringe round her loins. I had never seen her before. At least I did not remember her then. We looked at one another till she moved and began to come forward hesitatingly. I forbade the dogs to rise or bark. At last she came close enough to hear me as I spoke. She never took her eyes off mine, frightened, I saw, but fascinated. As I looked at her I loved her.”

He paused again. He seemed to be going over in his mind their first meeting - her words and his own. ${ }^{72}$

"She had seen me," he said, "the last time when I rode into the camp. That day I shot her only brother. It was months ago. I did not know it till after. She had heard me speak of Biame. Before this the mysteries of the men had enthralled her, and she had risked her life in attempting to get to understand them. ${ }^{73}$ She was Nini. She had heard them speak of me as Biame, the whirl of the boomerang, the rush and stab of the spear, the irresistible flash of the lightning. She would come to me now with an offering, and, though she should be consumed, it would be happiness. There was only one man left of the tribe of the Red Snake. She was of the tribe of the Sea Eel. It was lawful for the men of the Red Snake to marry the women of the Sea Eel, but the tribe of the Shark had utterly destroyed the Red Snake twelve moons past - all save this one man. I knew it, she said. I was Biame; what had she to tell me? Nevertheless, she would tell on. Well, this man was a great mystery man, and he alone of all the Sea Eel tribe, with whom he now lived, still hated and fought against Biame. ${ }^{74} \mathrm{He}$ had said he would kill me, and he had devoted me to swift death and the vengeance of the true Biame, having gone a week ago into the desert and to the boora in the hills to fast and pray. This morning he had come back and all had been made ready. Fourteen of the men had bound themselves to him with great oaths to kill me. ${ }^{75}$ Early in the morning of this night, just as the star rose which makes all the birds to sing, they would fall upon me in the house. I should be quite alone. They knew it. I listened to all she said and drew her to my knees and kissed her and called her by her name. Had I been wiser, I should have known of all this myself, but I had not. Now I remembered and understood. I loved her before she spoke. She came, bearing an offering. It was not to me that she was to be a victim, happy to be slain. I could only love her, even as Hadrian did Antinous, who died in the Nile waters, a sacred sacrifice to unknown powers."

There came a long silence. He sat there motionless, looking down, full of thought. 


\section{IV.}

At last he turned his head in the slow, deliberate way he had, as if turning the whole of his body with it. I cannot quite tell why, but I felt somehow as I suppose someone ${ }^{77}$ would do who had vivified the statue of a man of the old Pagan civilisations and was listening as it spoke. ${ }^{78}$ Perhaps it was his allusion to Hadrian and Antinous and my memory of hours spent in the cool and shadowy Louvre gallery in Paris before the supreme bust of the Bithynian, the wonderful record of his mysterious, voluptuous, mocking beauty, rising divinely derisive through suffering and agony and the passion and grief of others. ${ }^{79}$ And all the while there were the notes of the piano, the sweet and simple musical reverie of the white-clad girl with her upraised face in the light of the candles - the girl come back for this one hour, in despite of fate, from her bed in the grassy earth under the shadow of the city's western hills.

"As I was digging on through the quiet hours of the night," he said, "I realised the whole tale and wondered I had missed it so. And I knew the soul of the Red Snake and of Nini. The hut had no floor; it was only the beaten earth. ${ }^{80} \mathrm{I}$ had a pick and a spade, and I set to at once to dig a deep hole directly by the door - on the inside, I mean. ${ }^{81}$ Nini sat and watched me, her eyes glowing, and the dogs sat outside the threshold and watched. They had judged rightly that I should be quite alone. All the men and gins were away. Some were shepherding, some here, some there at their huts. I like to live in a hut for a week or two and then go on to another. That was before I started pearl-shell fishing. I liked the station-house on the shore better than any place I ever lived in. I like it still. But I dislike the steamers passing by it. That drives me inland wandering again. Nini called it her love-place - Nini! Nini ${ }^{82}$ The moon rose presently, and the light came in on me faintly from the left as I was working in the pit. ${ }^{83}$ She was not as full or as radiant as the night before, and there were still banks of misty cloud scarcely distinguishable right round the east and spreading to the north and south. When I had dug the pit so deep that I could not easily throw up more earth out of it, I ceased. ${ }^{84}$ I had packed the earth all round the room, banking it firmly, and making the pit several feet deeper. ${ }^{85}$ In one place on the far side of it, just opposite the door, I cut down the bank somewhat, so as to have a small firm platform to stand on. It was midnight before I had done, and then I ate food - bread, water, and fruit. Nini would not eat. She was getting frightened, and sat with her face between her knees, shivering. Then I made her go out down to the shore and wait for me there by a certain tree. She could go best by herself, and I knew we were being watched now. She stole out and away, using the shadow and the trees, and waiting till the moon was clouded. Then I whistled for Leper, and took him down to the shore with the dogs. I passed the tree and saw her lain along by the roots, but did not stop or say anything. I left the dogs with Leper in a good open place. He had the best chance of not being speared there, for I thought that, unless they actually met him, they would be taken up completely with me. Then I came back to the hut. I knew I must have passed among them, but I was quite safe. My hour was a fixed one. I had my rifle and two revolvers all loaded. That made thirteen. I wanted fourteen; so I would have to reload once. 
I had a torch ready stuck in the wall above the small platform, and a long piece of cord rolled round on a nail beside it. I left the door on the latch. By this time a slight sea breeze was blowing. ${ }^{86}$ They came up just before dawn. The false dawn is the converse of the after-glow - the bannered vanguard of the sun's coming, and the rear-guard of his going. ${ }^{87}$ Just as the false dawn arose, they rushed the door. I waited a few moments and struck a match, and touched the torch, which blazed up. ${ }^{88}$ They were all in the pit - every one of them. ${ }^{89}$ I shot them one after another as they presented their left sides. They were like rats in a bag. Only the last rat in a bag will bite your hand. I had fourteen to kill and one to save. As I shot out one cartridge from one of the revolvers; put in a new one, and clicked it round the four times before cocking, I saw there were only two alive. The sea breeze blowing from the east caught the swung-open door, which ran out almost due south, and poured into the room, clearing out the smoke..$^{90}$ They were almost all young men - men of the third or fourth grade. The Red Snake and the other one were lying back against the far side of the pit. They were both quite quiet, staring at me. ${ }^{91}$ The moonlight and the red glare of the torch mingled curiously. I shot the other one straight through the heart. I knew his face well. I had not spoken one word. Then I put down ${ }^{92}$ the revolver; took the cord from the nail, and jumped straight down onto the Red Snake..$^{93}$ I knew the whole tale now, and also how it regarded him and Nini. I caught his wrists and bound them. Then putting my feet on his shoulders, I pulled up his hands within reach and dragged him up by them. ${ }^{94}$ I whistled for Leper and the dogs, and presently scrambled out up onto the threshold with the cord. They came, the dogs first and then the horse, breaking through the bush. I got up onto Leper, lifted the Red Snake by his arm-pits and flung him across in front of me. ${ }^{95}$ Then we set out. The dawn was here now and I rode fast. The sun got up as we neared the boora. I ascended by the same gully as two sunsets ago, and stopped where I had stopped then. It was all chilly and dark here yet, but the flat, rocky summits that faced eastwards were just glinting with light. ${ }^{96}$ As we stopped, three or four gaunt bony dingoes started from the bushes and slouched away. I commanded the dogs not to follow. ${ }^{97}$ The dingoes went up to the gully a little and turned, looking at us and grumbling. There was a coolibar tree just by."

The girl, wandering away into vague music or snatches of other airs, returned suddenly to the melody full of smiles and tears, and struck the notes of it with greater firmness. I almost thought I heard her voice accompanying two or three of the notes.

"The coolibar is a crooked and stunted tree, always in watercourses and everywhere to the west of the Great Range, but rare here on the coast. ${ }^{98}$ I undid the cord from his wrists, and, drawing his arms behind his back, refastened them and cut off the remainder. ${ }^{99}$ With this I lashed his ankles. Then I lifted and lashed them up to the first partition of the coolibar's boughs, lying him on his back. As he looked up he could see his carving on the rock in the growing radiance of the golden light. ${ }^{100}$ We looked up at it together."

The words of the singer were clear and distinct now:

"The birds singing gaily that came at my call."101 
And then no more - only the melody, softer and softer.

"It was the Red Snake and Biame, the flash of the lightning. The Red Snake - square-snouted, thin, whip-like, furious - was in full back-leap at it with open jaws. ${ }^{102}$ The lightning was not the usual lightning - the zig-zag. It was the zigzag lost in a vague sheet — the summer lightning, the false lightning. The Red Snake would bite and consume the false Biame. The ancient god would slay the young wielder of his force, the reckless dispossessor and usurper. I turned to go. Then for the first time he opened his mouth. He said: 'The Red Snake is struck and broken and is to writhe helplessly and be consumed alive by the hateful dogs. The new Biame is the stronger. All is given to him. The land of the old Biame is his, and the life of his mouth and the love that comforted his limbs. ${ }^{103}$ Take all, but not yet without some vengeance-gift in return. The new Biame shall give of his own. The life that comes from him shall he give, and the love that shall comfort him, and then he shall rule and destroy as he will, till the hour of torment and impotence shall take hold of him also. Behold, before the black men were here the sacred land was here, and before the old Biame it was here, and after the white men are gone and after the new Biame is gone, it shall be here.' Then he closed his lips and I mounted and rode away. I had still much to do. I had to take all the men from the pit and lay them in a row in the sun for their friends to come and see, and fill it up again."104

“Home, home, sweet, sweet home!” broke out the voice with lingering passion, and then the melody again. ${ }^{105}$

"I looked back once as I came to the turn in the gorge. The dingoes were all round him, lolling their tongues out, grumbling and whining impatiently, glaring with their hollow, hungry eyes, working up their courage to attack and devour him."

"Home, home, sweet, sweet home!” And then, as the melody came, there came also a wild dark whirling of everything — waving trees and grass under dusky hills, snatches of birds' song and shouts and merry calls of children splashing in sunny shallows; wreathing mist and the divine derision of a rising face; towering black, flat rocks, sunlit and cut with temple figures of reptile and natural faces; a girl with great deep, dark, liquid eyes, full of love, gazing piteously, and then with grey eyes and a lighter face smiling sadly and essaying the clear notes her young virginal voice. Then all grew confused, whirling, thudding terribly like a train at full speed, convoluting and extending itself in mid-air like a long thin snake, and whirled away into the rushing darkness and silence.

What I remember next is lying in a dim, light-shot atmosphere with someone holding a glass of whisky to my lips. Then I spoke and said that I was sorry and that I must have fainted. I was not well — the work and the heat had been trying me very much the last few weeks. ${ }^{106}$ Power's face was there and Melvil's, and they were both very kind. Melvil's was even tender. 


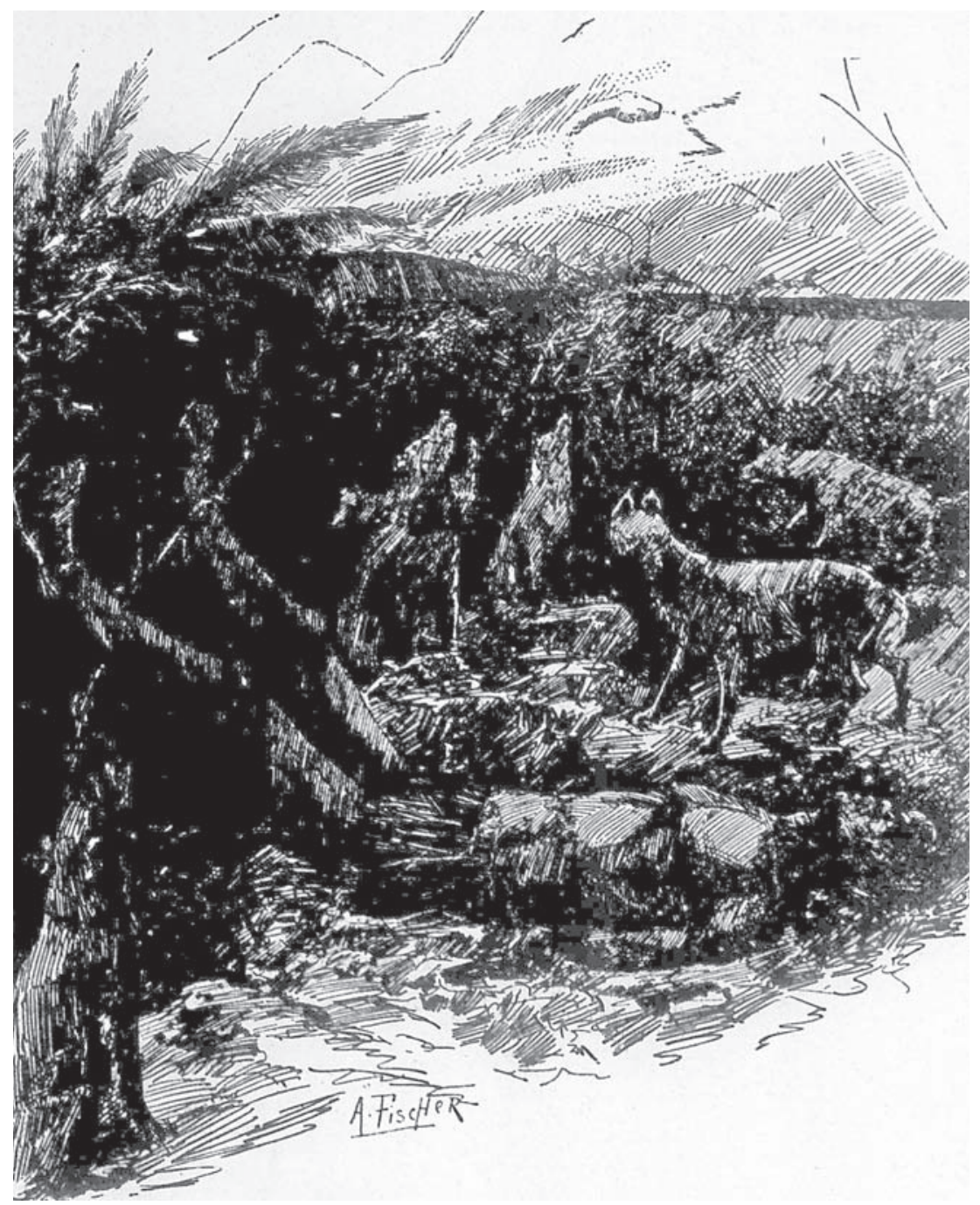

THE DOOM OF THE RED SNAKE.

"Then I lashed his ankles up to the first partition of the coolibar's boughs, lying him on his back. As he looked up he could see his carving on the rocks in the full blaze of the golden light."

Figure 2: Illustration by Amandus Julius Fischer (1859-1948) for 'The Red Snake' by Francis Adams in The Christmas Boomerang, 24 December 1988: 18. 


\section{Notes}

1 George street] George Street, Brisbane, (Australian Life, hereafter AL).

2 anyone I know,] any of my friends, (Christmas Boomerang, hereafter CB).

3 piece of humanity] human (CB); eccentric] abnormal (CB).

4 Frank Melvil of Maidenhair Passage is a thinly disguised portrait of Francis Lascelles (Frank) Jardine (1841-1919), whose home at Somerset on the tip of Cape York Peninsula overlooked Albany Passage.

5 In 1887, Francis Adams travelled by ship up the coast of Queensland to Port Darwin en route to China and Japan. Although he had remarried, his new wife (Ella Edith Goldstone) did not accompany him.

6 Algernon Charles Swinburne, Poems and Ballads (London: J.C. Hotten, 1866). The publication of this volume revived an Anglophone interest in Sappho and contributed to the development of a homoerotic strain in English decadent verse. Adams's alliterative phrase 'somnolent sweet winy airs' in the next sentence echoes Swinburne.

7 Pacific] Pacific, (AL); my overworked, sick, fevered personality] overworked, sick, fevered me (CB).

8 islands] islands, (AL).

9 left, a large coral island to the right;] left; a large coral island to the right, (CB).

10 mangroves,] mangoes (CB).

11 graceful and serpentine] graceful serpentine (CB).

12 piles,] piles (AL).

13 onto] on to (AL).

14 The phrase 'Eden of bland repose' is from Edgar Allan Poe, 'To F...', The Raven and Other Poems, 1845 (London: Wiley and Putnam, 1846), 25. 'F...' here refers to the poet Frances Sargeant Osgood (1811-50). Earlier versions of this poem — 'To Mary' (Southern Literary Messenger, July 1835) and 'To One Departed' (Graham's Magazine, March 1842) — also contain the same phrase. Although it is suggestive of both Poe and Swinburne, I have been unable to identify the following phrase, 'where the sea winds sing and sunlight smiles': it is probably a misquotation by Adams. Poe's 'To F...' ends with the lines: 'Serenest skies continually / Just o'er that one bright island smile.'

15 Brisbane and at Christmas too.] Brisbane. (AL).

16 boats,] boats (CB).

17 why — as the Yankees say] — why, as the Yankees say (CB).

18 know.] know, Acheson. (AL) The narrator is never named in the Christmas Boomerang version of 'The Red Snake'. In Australian Life, Acheson reappears as the narrator of 'Long Forster' (pp. 137-47), and 'The Hut by the Tanks' (pp. 177-91).

19 Frank Jardine was the grandson of Sir Alexander Jardine, $6^{\text {th }} \mathrm{Bt}$, and the nephew of naturalist Sir William Jardine, $7^{\text {th }}$ Bt.

20 there.] there? (AL).

21 Frank Jardine was removed from his post as Police Magistrate in 1875 after many complaints about his ill-treatment of Aborigines and his exploitation of his government post for private gain.

22 In 1879, following the non-fatal spearing of two white men by Aborigines at Cape Bedford north of Cooktown, Sub-Inspector O'Connor led his Native Police troopers on a reprisal attack in which 24 Aborigines were massacred. (Cape Bedford is now part of the Hopevale Aboriginal Community.) Reginald Spencer Browne, associate editor of the Brisbane Courier and a friend and admirer of Francis Adams, gives an account of the massacre in A Journalist's Memories (Brisbane: The Read Press, 1927), 27, where he claims that 28 'bucks' were killed. As a former editor of the Cooktown Herald, Spencer Browne was well informed about northern Queensland. 
Spencer Browne is the most likely source of Adams' information about both the Cape Bedford massacre and Frank Jardine.

23 'Long Forster', in the eponymous story by Adams which opens the 'Up-Country' section of Australian Life, is also described (20) as 'about the softest-hearted cuss ever lived. He wouldn't hurt a fly.' Nonetheless, as revenge for the spearing of a mate, he corners and kills thirteen Aborigines, including women, with a tomahawk and his bare hands. This story first appeared under the pseudonym Proteus as 'Tony Forster' in The Boomerang, 5 May 1888: 11.

25 chap] man (CB).

26 have a chat] spin a yarn (AL); [at six and have chow,] at 6 and have chow (CB); you're] your (AL); Christmas Day] Christmas-day (AL).

27 For the term 'chin-chin', see Sir Henry Yule, Hobson-Jobson: A Glossary of Colloquial AngloIndian Words and Phrases, and of Kindred Terms, Etymological, Historical, Geographical and Discursive, new ed. edited by William Crooke (London: J. Murray, 1903), 200: 'In the "pigeon English" of Chinese ports this signifies "salutation, compliments," or "to salute," and is much used by Englishmen as slang in such senses. It is a corruption of the Chinese phrase ts'ingts'ing, Pekingese ch'ing-ch'ing, a term of salutation answering to "thank-you," "adieu." The entry (201) also cites W. Gill, The River of Golden Sand (1883), 41: 'But far from thinking it any shame to deface our beautiful language, the English seem to glory in its distortion, and will often ask one another to come to "chow-chow" instead of dinner; and send their "chinchin," even in letters, rather than their compliments; most of them ignorant of the fact that "chow-chow" is no more Chinese than it is Hebrew; that "chin-chin," though an expression used by the Chinese, does not in its true meaning come near to the "good-bye, old fellow," for which it is often used, or the compliments for which it is frequently substituted.' sail] pearl-shell (AL).

29 George-street] George Street, (AL).

30 Christmas Day] Christmas-day (AL).

31 Manila] Manilla in (AL); [Hongkong] Hong Kong (AL).

32 After the word 'faint' in the Christmas Boomerang version, two lines of extraneous text have been erroneously inserted: 'the office a usual to see if any work was wanted from me for the next morning's issue, but there'.

33 boarding-house,] boarding-house; (CB); George street] George Street (AL). Adams describes what is now the Brisbane CBD (North Quay and George Street) and the South Bank precinct (South Brisbane, across the river).

34 The reference is to Toowong Cemetery, at the foot of Mt Coot-tha. Adams' first wife, Helen Elizabeth Uttley, died in Brisbane in July 1886 of rheumatic fever and complications from the birth in June of their son Leith, who died in November of that year; both are buried in Toowong Cemetery. garden gate,] garden-gate (CB); and,] and (AL).

36 left.] right (CB).

37 affects,] loves, (CB).

38 door-windows] garden windows (AL); right door-window.] right window. (AL).

39 brow, with its broad frowning bar,] brow with its broad frowning bar (CB).

40 fixed inscrutable resolve of a sphinx.] bold, fixed, and inscrutable resolve of a sphinx. (AL).

41 impassive,] impassive (CB).

42 by the left door-window,] to the left, (AL).

43 the man's face] Melvil's face (CB).

44 wretched,] wretched (CB).

45 'Madeline Brown'] 'Maud Harcourt' (AL) Francis Adams was the author of a sensational murder mystery, Madeline Brown's Murderer (Melbourne: Kemp and Boyce, [1887]). By substituting the title 'Maud Harcourt' and naming the framing narrator Acheson, Adams distances the narrator from himself in the later version. Madeline Brown's Murderer was republished as The Murder of Madeline Brown (Melbourne: Text, 2000), with an introduction by Shane Maloney. 
46

47

48

49

50

51

52

53

54

55

56

57

me:] me; (AL).

miserable,] miserable (AL).

suppose?"] suppose." (CB).

civilisation,] civilisation; (AL).

to] into (CB).

has] had (AL).

singing,] singing; (CB).

untutored,] untutored (CB); "musical”] pseudo-“musical” (AL).

white,] white (CB).

him,] him (CB).

blackfellows] black fellows (AL).

mysteries.”] Mysteries.” (AL).

several] several, (AL); runs.] runs, (CB).

Lepers); put two revolvers in my belt (AL); take my rifle and] Lepers), put two revolvers in my belt and (CB).

interested me,] interested me (CB).

in North America, I unravelled the Red Indian carvings] in South America on the Amazon, I unravelled the Indian carvings (AL).

Biame (also Baiame or Byamee) is the Great Spirit of the dreaming of several language groups of Indigenous people in south-eastern Australia, and is associated with initiation sites (boras). He is depicted in a famous Wiradjuri rock painting near Singleton as a man with staring eyes and extremely elongated arms. Following the usage of the English Presbyterian missionary William Ridley, who translated the language of the Kamilaroi people in 1866, Baiame is sometimes identified with the Christian God. The story told here by Adams does not appear to have any real connection with Cape York, although a white man may well have tried to pass himself off as the 'Biame' of southern language groups. See William Ridley, Kamilaroi, Dippil, and Turrubul: Languages Spoken by Australian Aborigines (Sydney: Government Printer, 1875). See also H.M. Carey, 'The Land of Byamee: K. Langloh-Parker, David Unaipon, and Popular Aboriginality in the Assimilation Era', in Journal of Religious History, 22(2) (1998): 200-218.

mysteries,] Mysteries, (AL).

gorges.] gullies (AL).

gully] gulley (AL).

it] the rock (CB).

over the sea and the plans in the east.] in the east over the sea and the coast. (AL).

dingoes] dingos (CB).

cutting,] cutting (CB).

a sweet, lingering passion] a lingering passion (AL).

were] were were (AL).

over] ever (AL).

mysteries] Mysteries (AL).

of all] of (CB).

the men] the young men (AL).

After the death by drowning in the Nile of his Bithynian-born lover, Antinous, Roman Emperor Hadrian was inconsolable and decreed that Antinous be deified. The cause of Antinous's death is unknown, but Melvil here refers to the tradition that Antinous was sacrificed, or sacrificed himself, perhaps to restore Hadrian's health.

someone] a man $(\mathrm{CB})$.

a man] some man (CB).

The bust of Antinous held by the Louvre is the so-called 'Antinous of Ecouen' (Accession number Ma 1082 [MR 413], presented to the Louvre in 1793), an eighteenth century copy of an original found at Hadrian's Villa in Tivoli during the Renaissance, and widely copied.

earth.] sand. (AL).

spade,] spade (CB). 
82 love-place-] love-place, (CB).

83 faintly from the left] from the left (CB).

84 earth] sand (AL).

85 earth] sand (AL).

86 By this time a slight land breeze was blowing.] A slight land breeze was blowing. (AL).

87 bannered] coloured (AL).

88 match] match, (AL).

89 every one] everyone (CB).

90 sea breeze blowing from the east] land breeze blowing from the west (AL).

91 quite quiet,] both quite quiet (AL).

92 Then I put down] I put down (CB).

93 onto] on to (AL).

94 Then putting] Then I putting (CB).

95 the cord. They] the cord, they (CB).

96 just glinting] gold (CB).

97 commanded] told (CB).

98 coast.] east (CB) Eucalyptus coolabah grows widely on flood plains throughout Australia, in both coastal and inland areas. The description here of the tree as 'crooked and stunted' is curious: the coolabah (as it is generally spelt today) grows to about 15 metres, with wide, spreading branches; however, its lower bark is furrowed.

99 wrists,] wrists (CB).

100 growing radiance] full glow (CB).

101 No quotation marks in CB. These words, like the following snatches of song, are from 'Home Sweet Home' by American John Howard Payne. They occur in his 1823 opera, Clari; or the Maid of Milan. In 1852, the English composer Sir Henry Bishop adapted Payne's words and wrote the melody that is still popular today.

102 The Red Snake - square-snouted, thin, whip-like, furious - ] The Red Snake, square-snouted, thin, whip-like, furious, (CB).

103 his,] his (AL).

104 a row in the sun for their friends to come and see,] a row in the sun, (CB).

105 "Home, home, sweet, sweet home!"] "Home, home, sweet, sweet home," (CB).

106 well — the work] well; the work (CB). 